\title{
Low Molecular Weight Organic Acids Increase Cd Accumulation in Sunflowers through Increasing Cd Bioavailability and Reducing Cd Toxicity to Plants
}

\author{
Hongfei Lu ${ }^{1} \mathbb{C}$, Dongmei Qiao ${ }^{1, *}$, Yang Han ${ }^{1,2}$, Yulong Zhao ${ }^{1}$, Fangfang Bai ${ }^{1,3}$ and Yadan Wang ${ }^{1}$ \\ 1 Farmland Irrigation Research Institute, Chinese Academy of Agricultural Sciences, Xinxiang 453002, China; \\ luhongfei@caas.cn (H.L.); 13940585693@163.com (Y.H.); zhaoyulong@caas.cn (Y.Z.); \\ baifangfang@caas.cn (F.B.); wangyadan1108@163.com (Y.W.) \\ 2 Agricultural Water Soil Environmental Field Research Station of Xinxiang, Chinese Academy of \\ Agricultural Sciences, Xinxiang 453002, China \\ 3 Key Laboratory of High-Efficient and Safe Utilization of Agriculture Water Resources, Chinese Academy of \\ Agricultural Sciences, Xinxiang 453002, China \\ * Correspondence: qiaodongmei@caas.cn
}

\section{check for} updates

Citation: Lu, H.; Qiao, D.; Han, Y.; Zhao, Y.; Bai, F.; Wang, Y. Low Molecular Weight Organic Acids Increase $\mathrm{Cd}$ Accumulation in Sunflowers through Increasing Cd Bioavailability and Reducing Cd Toxicity to Plants. Minerals 2021, 11 243. https://doi.org/10.3390/ $\min 11030243$

Academic Editors: Minhee Lee and Wooyong Um

Received: 10 February 2021

Accepted: 23 February 2021

Published: 26 February 2021

Publisher's Note: MDPI stays neutral with regard to jurisdictional claims in published maps and institutional affiliations.

Copyright: (c) 2021 by the authors. Licensee MDPI, Basel, Switzerland. This article is an open access article distributed under the terms and conditions of the Creative Commons Attribution (CC BY) license (https:// creativecommons.org/licenses/by/ $4.0 /)$.

\begin{abstract}
The use of low molecular weight organic acids (LMWOAs) for the phytoremediation of heavy metals has become a promising technique. We chose five kinds of organic acids (oxalic acid (OA), acetic acid (AA), tartaric acid (TA), malic acid (MA), and citric acid (CA)) with six application rates $(1,2,3,4,5$, and $6 \mathrm{mmol} / \mathrm{kg}$ ) and planted sunflowers (Helianthus annuus L.) in Cd-polluted soil to study the efficiency of the phytoremediation of $\mathrm{Cd}$ and the degree of $\mathrm{Cd}$ toxicity to plants. Treatment with no acid application served as the control (CK). We analyzed the plant height dry matter and the Cd and nonprotein sulfhydryl (NPT) contents in the soil and plant tissues. OA, AA, TA, MA, and CA increased plant heights by $17.6-47.40 \%, 21.25-39.17 \%, 12.5-35.52,5.10-30.50 \%$, and $16.15-49.17 \%$, respectively; shoot biomass of the sunflowers was increased except with MA. NPT decreased under LMWOA application, which, in the roots, increased with the increase in root $\mathrm{Cd}$ under LMWOA treatment; however, there was no obvious relationship in the stems and leaves. The composition of $\mathrm{Cd}$ in the soil changed significantly under the LMWOA treatments compared to the $\mathrm{CK}$, and the changes in carbonate $\mathrm{Cd}$ and Fe-Mn oxide $\mathrm{Cd}$ were the most prominent. The plant Cd accumulation of OA, AA, TA, MA, and CA increased by $43.31 \%, 55.25 \%, 48.69 \%, 0.52 \%$, and $32.94 \%$, respectively, and the increase in root $\mathrm{Cd}$ content and shoot dry matter quality promoted the increase in $\mathrm{Cd}$ accumulation. The LMWOAs were more likely to affect the phytoremediation of $\mathrm{Cd}$ by changing total $\mathrm{P}(\mathrm{TP})$ rather than total $\mathrm{N}(\mathrm{TN})$.
\end{abstract}

Keywords: sunflowers; Cd; low molecular weight organic acids; nonprotein sulfhydryl; biomass

\section{Introduction}

With the rapid development of industry, the number of heavy metal-contaminated lands in different regions of the world has increased significantly [1-3]. In particular, mining, industrial water, and battery factories are responsible for polluting a lot of farmland with $\mathrm{Cd}, \mathrm{Pb}, \mathrm{Cu}$, etc. [4,5], which leads to heavy metals penetrating the food chain and thereby entering the human body, threatening people's lives and health [6-9]. Heavy metal dissipation with mineral fertilizers also adds considerable amounts of heavy metals to agricultural soil [10]. At present, the research on phytoremediation of heavy metal pollution has attracted wide attention [11-14], mainly focusing on two aspects: the enrichment ability and the biomass of heavy metals in plants.

Important progress has been made in the screening of heavy metal hyper accumulators, such as Celosia argentea L. [15], Spinacia oleracea L. [16], Populus and Salix [17], and Jack Bean [18]. The bioavailability of $\mathrm{Cd}$ in soil is an important factor affecting the uptake of $\mathrm{Cd}$ by plants, and exchangeable and carbonate forms are the main forms of $\mathrm{Cd}[19,20]$. The 
efficiency of phytoextraction is related to the ability of plants to accumulate the toxicant, and there are significant differences in the remediation of heavy metals among different crops [21,22].

Low molecular weight organic acids (LMWOAs) can increase the bioavailability of heavy metals in soils by forming water-soluble complexes with said metals [23], as well as enhancing their phytoextraction efficiencies $[15,24,25]$. LMWOAs may inhibit or facilitate $\mathrm{Cd}^{2+}$ transport under different environmental conditions [26]. The desorption of heavy metals by different organic acids is different [27-29], which is due to the differences in the complexation strength between organic acids and heavy metals [30]. Therefore, for different crops, the effect of different organic acids on these two aspects needs to be quantitatively evaluated, and the reasons for the change need to be analyzed.

Nonprotein sulfhydryl (NPT) compounds mainly include glutathione (GSH), phytochelatin (PC), and cysteine (Cys), and the complexation of heavy metals with sulfhydryl compounds forms the response of plants to heavy metal stress [31]. NPT is induced by various metals and metalloids in cells [32], and GSH can scavenge several potentially toxic ROS (such as O-2 or Oh) and can help cells cope with the oxidative stress caused by oxidation; meanwhile, PC shows hypersensitivity to Cd stress [33]. Studying the change of NPT is helpful for determining the main factors for plants to improve the accumulation of heavy metals.

$\mathrm{Cd}$ is a very toxic and ubiquitous heavy metal in soil that seriously threatens food safety in China [15], and higher Cd in soil could produce toxic effects on crops, thereby inhibiting crop growth and reducing biomass [34]. LMWOAs could enhance nutrient uptake and translocation into the aboveground parts of plants [35]. Sunflowers have broad application potential in the remediation of soil $\mathrm{Cd}$ pollution because of their large biomass, strong $\mathrm{Cd}$ tolerance, and low requirement of water and fertilizer, and they can be used as biomass energy [36-39]. The Cd absorption of sunflower increased linearly with the increase in Cd levels [40], although Cd inhibited the growth of oil sunflower, the application of plant growth regulators could improve the Cd removal efficiency [41]. In the present study, we investigated the phytoextraction efficiency of sunflowers using Cd-polluted soil with a Cd content of $19.8 \mathrm{mg} / \mathrm{kg}$. In addition, we assessed the effects of oxalic acid (OA), acetic acid (AA), tartaric acid (TA), malic acid (MA), and citric acid (CA) on $\mathrm{Cd}$ mobilization and total $\mathrm{Cd}$ accumulation. The objectives were (i) to investigate the effectiveness of these five LMWOAs in phytoremediation and (ii) to clarify the role of NPT in the phytoremediation of $\mathrm{Cd}$.

\section{Methods and Materials}

\subsection{Soil Preparation}

This experiment was conducted from October 2018 to January 2019 in a greenhouse $\left(20 \times 50 \mathrm{~m}^{2}\right)$, located at the Hongmen Experimental Station of Farmland Irrigation Research Institute, Chinese Academy of Agricultural Sciences, in Henan province (latitude $51^{\circ} 5^{\prime} 45^{\prime \prime} \mathrm{N}$ and longitude $\left.113^{\circ} 55^{\prime} 5^{\prime \prime} \mathrm{W}\right)$. The soil was collected from a Cd-contaminated area (soil Cd concentrations varied from 3.38 to $44.94 \mathrm{mg} / \mathrm{kg}$ ) [42] near a battery factory $(35.35696 \mathrm{~N}, 113.839256 \mathrm{E})$ in 2018 , of which the texture is silt clay loam, and the percentages of particle size for $0.02-2 \mathrm{~mm}, 0.002-0.02 \mathrm{~mm}$ and $<0.002 \mathrm{~mm}$ are $27.88 \% 54.77 \%$ and $17.35 \%$, respectively. The total amount of $\mathrm{Cd}$ in the soil was $19.5 \mathrm{mg} / \mathrm{kg}$ (measured by the atomic absorption spectrometry method). The total amounts of soil nitrogen, phosphorus, and potassium were 1.14, 0.63 , and $0.086 \mathrm{~g} / \mathrm{kg}$, respectively. The soil organic matter content was $2.70 \%$ and the $\mathrm{pH}$ was 8.20 . The soil was first air-dried for three months prior to passing through a $2 \mathrm{~mm}$ sieve to remove debris. It was then fertilized with base fertilizers (analytical grade, Tianjin Bodi Chemical Co., Ltd., Tianjin, China): $18.44 \mathrm{~g} / \mathrm{kg}$ of urea, $12.2 \mathrm{~g} / \mathrm{kg}$ of $\mathrm{KH}_{2} \mathrm{PO} 4$, and $50.2 \mathrm{~g} / \mathrm{kg}$ of $\mathrm{KNO}_{3}$ (fertilizer mass/soil mass) with Cd content of $0 \mathrm{mg} / \mathrm{kg}$ [43]. 


\subsection{Experimental Design and Sampling}

Xianrun 2 (Helianthus annuus Linn., Xianrui Seed Technology Co., Ltd., Beijing, China) was used as the test material. Two seeds were sown in the middle of each pot on 2 October 2018. After all seedlings had emerged four days later, on October 6, the seedlings in each pot were thinned to one. Water was sprayed on the soil surface in each pot during the experiment to maintain its soil moisture at $70-100 \%$ of the soil field capacity. All pots were weighed daily to estimate the water loss from evapotranspiration, and water was added until its content was $100 \%$ of the field capacity whenever the soil moisture was less than $70 \%$ of the field capacity. We sprayed solutions of OA, AA, TA, MA, and CA of 1, 2, 3, 4, 5, and $6 \mathrm{mmol} / \mathrm{kg}$ (mass of acid/mass of soil) onto the soil surface in different pots at 20 days after seedling emergence, based on the application rates used in the literature $[43,44]$. Table 1 shows the chemical properties of the five used organic acids. Pots without added acids were used as controls $(\mathrm{CK} ; 0 \mathrm{mmol} / \mathrm{kg}$ ). Overall, there were 31 treatments, each with three replicates. The sunflower plants were harvested on 9 January 2019, and the test period lasted 100 days. The plants were divided into four parts: roots, stems, leaves, and buds, which were all packed into paper bags. Rhizosphere soil taken from each pot was thoroughly mixed and then sealed in a plastic bag before being frozen at $-80^{\circ} \mathrm{C}$ until chemical analysis.

Table 1. Abbreviations and concentration of the five low molecular weight organic acids (Shanghai Aladdin Biochemical Technology Co., Ltd., Shanghai, China).

\begin{tabular}{ccc}
\hline Acid & Abbreviation & Concentration (\%) \\
\hline Glacial acetic acid & AA & 99.8 \\
Oxalic acid & OA & 99.99 \\
Citric acid monohydrate & CA & 99.99 \\
DL-malic acid & MA & 99.99 \\
DL-tartaric acid & TA & 99.99 \\
\hline
\end{tabular}

\subsection{Measurement}

\subsubsection{Plant Height, Biomass, and Nonprotein Sulfhydryl (NPT)}

The plant height from the soil surface to the highest point was measured using a meter stick $(100 \mathrm{~cm})$ on 26 November 2018 . The roots and shoots of the sunflower plants were washed thoroughly with both tap and deionized water. Next, they were sterilized at $105^{\circ} \mathrm{C}$ for $30 \mathrm{~min}$, and then dried at $75^{\circ} \mathrm{C}$ until the mass was constant. The dry weights of the sunflower roots and shoots (stems, leaves, and buds) were measured.

The NPT of the stems, leaves, and buds at harvest was determined by the method of Rama and Prasad [45]. The reaction system was as follows: $1 \mathrm{~mL}$ of supernatant, $1.85 \mathrm{~mL}$ of $0.2 \mathrm{~mol} / \mathrm{L}$ Tris $\mathrm{HCl}(\mathrm{pH}=8.2$ ), and $0.15 \mathrm{~mL}$ of $10 \mathrm{mmol} / \mathrm{L}$ 2-nitrobenzoic acid (DTNB). After reaction for $20 \mathrm{~min}$, the absorbance was measured at $412 \mathrm{~nm}$ with TECAN infinite M200, with no DTNB as the blank.

\subsubsection{Soil Index}

Soil total N (TN) and total P (TP) were measured using an AA3 flow analyzer (Brown Rupee Pte Ltd.) [46]. Available phosphorus (AK) was determined using flame photometry [47].

\subsubsection{Cadmium in the Plant Tissues and Soil}

The Cd content in the roots, stems, leaves, and buds was measured. Ground plant samples, each weighing $0.2 \mathrm{~g}$, from each plant component were mixed with $10 \mathrm{~mL}$ of pure concentrated nitric acid (Sinopharm Chemical Reagent Co., Ltd., Shanghai, China) in a digestion tube and soaked for $7-8 \mathrm{~h}$ at room temperature $\left(24 \pm 1.0^{\circ} \mathrm{C}\right)$. The total $\mathrm{Cd}$ in the soil was measured using the same method as that used for plants using a graphite furnace atomic absorption spectrophotometer (AA-6300FG, Japan) [43]. We also measured 
exchangeable $\mathrm{Cd}$, carbonate $\mathrm{Cd}$, Fe-Mn oxide $\mathrm{Cd}$, organic $\mathrm{Cd}$, and residual $\mathrm{Cd}$ using the synchronous extraction method following the protocol presented in the literature [48].

The transport factor $(T F)$, bioconcentration factor $(B F)$, and bioavailability coefficient $(B C)$ were calculated as follows:

$$
\begin{gathered}
T F=\mathrm{Cd} \text { in shoot } / \mathrm{Cd} \text { in root } \\
B F=\mathrm{Cd} \text { in shoot } / \mathrm{Cd} \text { in soil } \\
B C=(\text { Exchangeable } \mathrm{Cd}+\mathrm{Carbonate} \mathrm{Cd}) / \text { soil } \mathrm{Cd}
\end{gathered}
$$

\subsection{Statistical Analysis}

All data were analyzed using analysis of variance (ANOVA) with SPSS 19.0 (SPSS Inc, Chicago, IL, USA), and each treatment contains three replicates. Multiple comparisons were made using Duncan's new multiple range test (MRT). In all analyses, differences were considered significant at $p<0.05$. Correlation analysis based on Pearson's method and on principal co-ordinates analysis (PCoA) was carried out using R 3.6.0.

\section{Results}

\subsection{Plant Height and Biomass}

Figure 1 shows plant heights on 26 November 2018 and biomass at harvest. The LMWOAs increased the plant height of the sunflowers (Figure 1a), with OA, AA, TA, MA, and CA increasing by $17.6-47.40 \%, 21.25-39.17 \%, 12.5-35.52 \%, 5.10-30.50 \%$, and $16.15-49.17 \%$, respectively, compared to $\mathrm{CK}$. In addition, the plant heights under $1 \mathrm{mmol} / \mathrm{kg}$ of $\mathrm{OA}$ and $\mathrm{TA}, 2 \mathrm{mmol} / \mathrm{kg}$ of AA and MA, and $4 \mathrm{mmol} / \mathrm{kg}$ of CA had significant differences with CK $(p<0.05)$.

The application of microorganisms did not significantly reduce the biomass of the roots and shoots, and $3 \mathrm{mmol} / \mathrm{kg}$ of OA, $5 \mathrm{mmol} / \mathrm{kg}$ of AA, $4 \mathrm{mmol} / \mathrm{kg}$ of TA and CA, and $2 \mathrm{mmol} / \mathrm{kg}$ of MA significantly increased the biomass of the roots and shoots (Figure $1 \mathrm{~b}, \mathrm{c}$ ). The mean biomass of shoots for OA, AA, TA, MA, and CA treatments increased by $59.18 \%$, $66.36 \%, 66.92 \%, 11.23 \%$, and $63.34 \%$, respectively.

\subsection{Cd Form in Soil}

The order of $\mathrm{Cd}$ content in rhizosphere soil was carbonate $\mathrm{Cd}>$ exchangeable $\mathrm{Cd}>$ Fe-Mn oxide $\mathrm{Cd}>$ residue $\mathrm{Cd}>$ organic $\mathrm{Cd}$, indicating that the change of soil $\mathrm{Cd}$ content was mainly determined by the first three forms of $\mathrm{Cd}$. The carbonate $\mathrm{Cd}$ content was increased under OA treatment (Figure 2a), which increased by $51.46 \%, 41.65 \%$, and $43.73 \%$ $(p<0.05)$ under 4,5 , and $6 \mathrm{mmol} / \mathrm{kg}$, respectively; however, OA treatment decreased the content of Fe-Mn oxide Cd, with 2, 3, 4, and $6 \mathrm{mmol} / \mathrm{kg}$ resulting in significant decreases of $50.44 \%, 49.40 \%, 45.87 \%$, and $48.35 \%$, respectively $(p<0.05)$.

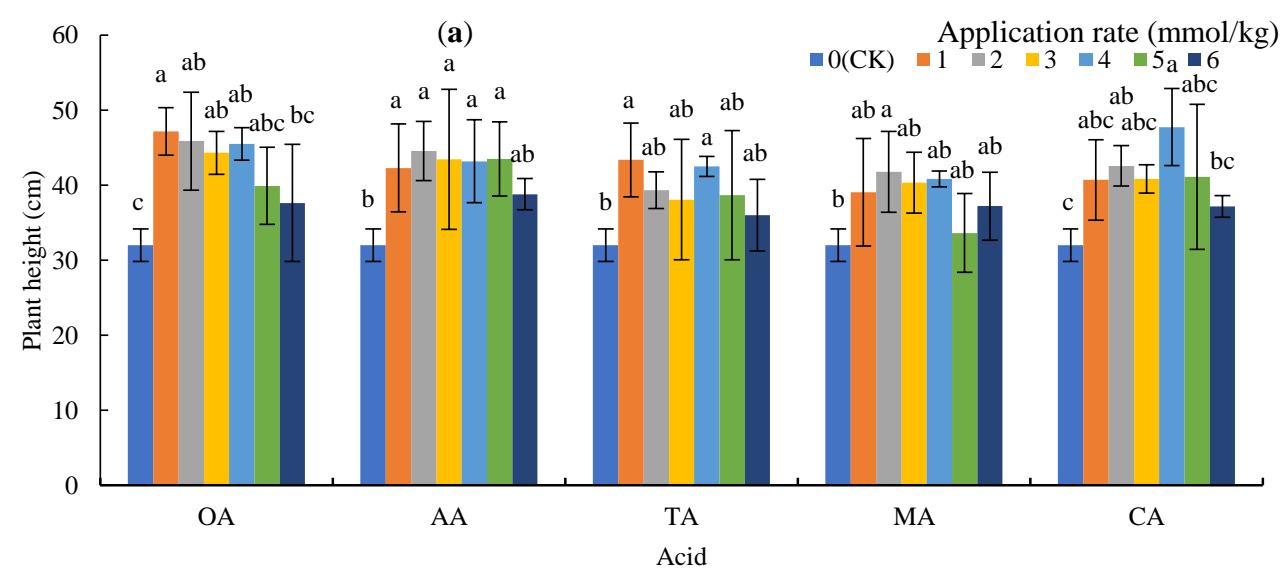

Figure 1. Cont. 

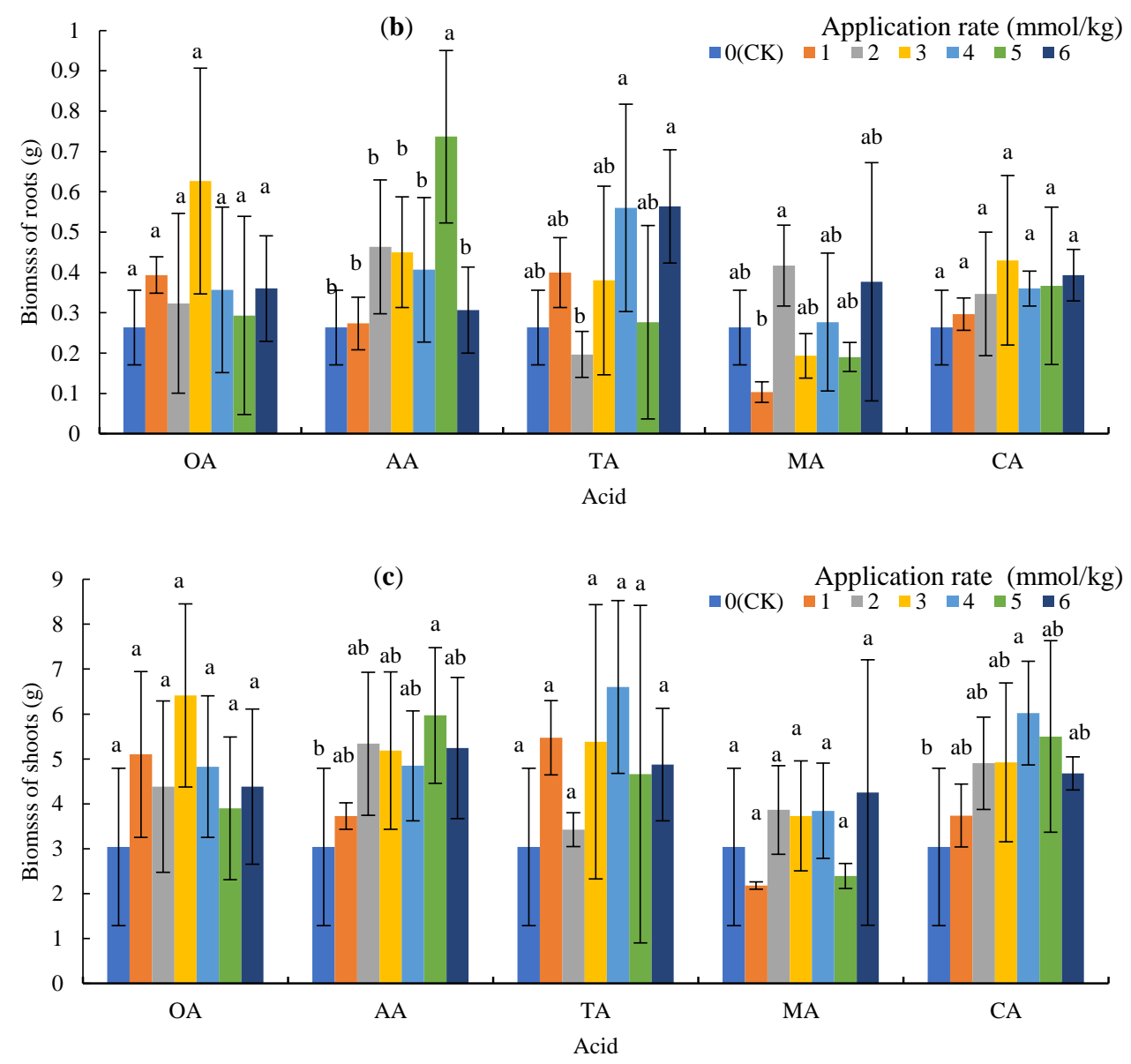

Figure 1. Plant height and biomass under low molecular weight organic acid (LMWOA) treatments and the control (CK). (a) Plant height; (b) biomass of the roots; (c) biomass of the shoots. Different lowercase letters show significant differences for $p<0.05$.

The application of AA increased the content of carbonate Cd (Figure 2b), with the $4 \mathrm{mmol} / \mathrm{kg}$ treatment resulting in significant differences compared to the CK $(54.65 \%$, $p<0.05)$; meanwhile, the content of Fe-Mn oxide $\mathrm{Cd}$ under $1-6 \mathrm{mmol} / \mathrm{kg}$ decreased by $36.72-52.01 \%(p<0.05)$. Additionally, exchangeable $\mathrm{Cd}$ under the $2-5 \mathrm{mmol} / \mathrm{kg}$ treatments also deceased, with the contents following the $5 \mathrm{mmol} / \mathrm{kg}$ treatment being the most significantly different.

As Figure $2 \mathrm{c}$ shows, the application of TA increased the content of exchangeable $\mathrm{Cd}$ and carbonate $\mathrm{Cd}$ with no significant difference to the $\mathrm{CK}$, but the $3 \mathrm{mmol} / \mathrm{kg}$ treatment decreased Fe-Mn oxide Cd by $57.86 \%(p<0.05)$ compared to the CK.

The application of MA increased carbonate $\mathrm{Cd}$ in the soil by $45.27-72.95 \%(p<0.05)$ and decreased Fe-Mn oxide Cd by $4.03-30.69 \%$ (Figure 2d), while the results of the $2-6 \mathrm{mmol} / \mathrm{kg}$ treatment were significantly difference compared to the CK. In addition, the exchangeable $\mathrm{Cd}$ after the $5 \mathrm{mmol} / \mathrm{kg}$ treatment and the residue $\mathrm{Cd}$ after the $6 \mathrm{mmol} / \mathrm{kg}$ treatment were significantly lower than the contents in the CK $(p<0.05)$.

The application of CA reduced exchangeable Cd and Fe-Mn oxide Cd by $16.02-43.95 \%$ and $29.46-50.48 \%$, but increased carbonate Cd by $19.73-76.34 \%$, when compared to the CK (Figure 2e).

\subsection{Nonprotein Sulfhydryl (NPT) in Plant Tissues}

As Figure 3 shows, the NPT in the plant tissues showed as root $>$ stem $>$ leaf. Compared to the CK (Figure 3a), the application of OA significantly reduced the content of NPT in the roots by $14.11-43.79 \%(p<0.05)$. Additionally, the content of NPT in the stems under the $1,3,4$, and $6 \mathrm{mmol} / \mathrm{kg}$ treatments significantly decreased by $40.83 \%, 13.44 \%, 25.32 \%$, 
and $23.51 \%$, respectively $(p<0.05)$, while in the leaves under the $2,3,4$, and $6 \mathrm{mmol} / \mathrm{kg}$ treatments, it significantly decreased by $51.09 \%, 41.12 \%, 39.56 \%$, and $29.60 \%$, respectively $(p<0.05)$.
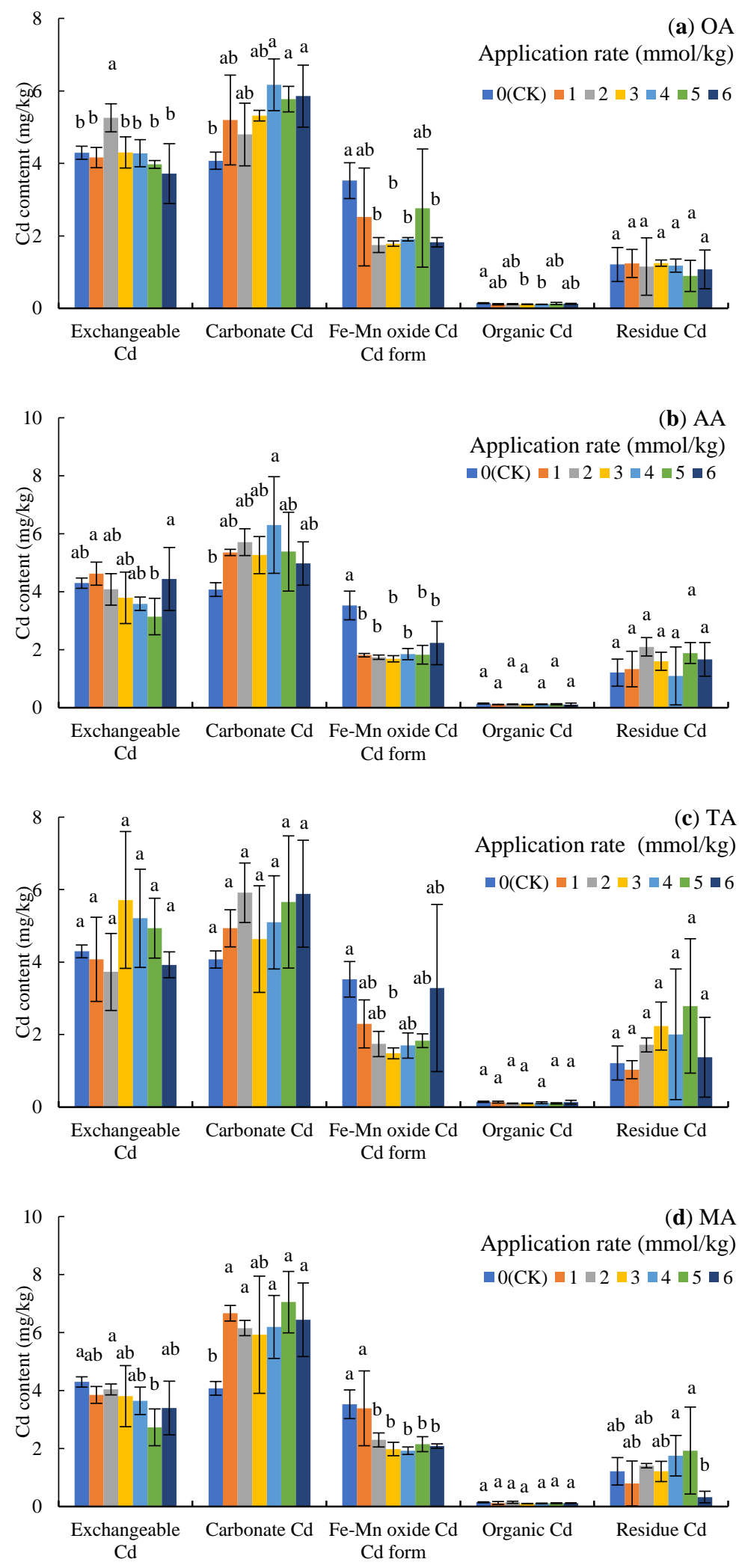

Figure 2. Cont. 


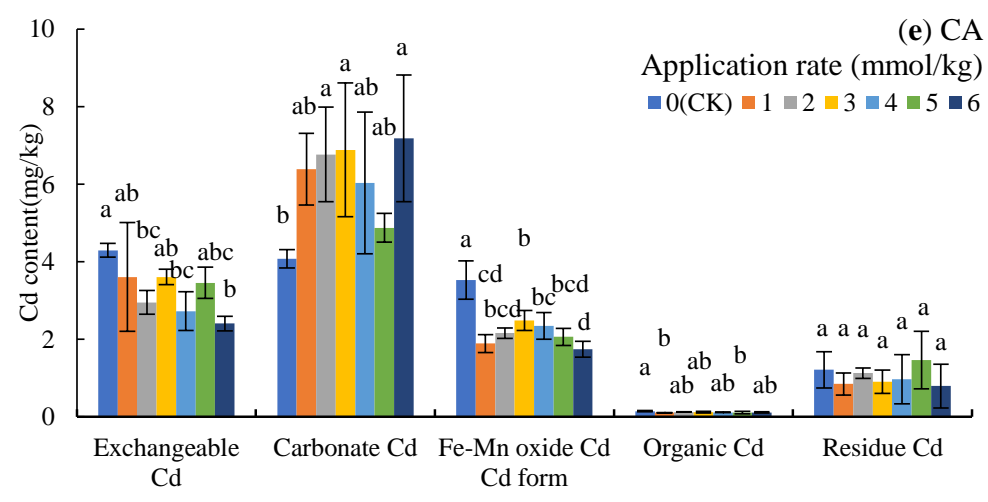

Figure 2. Cd content of different forms in the soil under LMWOA treatments and the CK; (a) oxalic acid (OA), (b) acetic acid (AA), (c) tartaric acid (TA), (d) malic acid (MA), and (e) citric acid (CA). Different lowercase letters show significant differences for $p<0.05$.
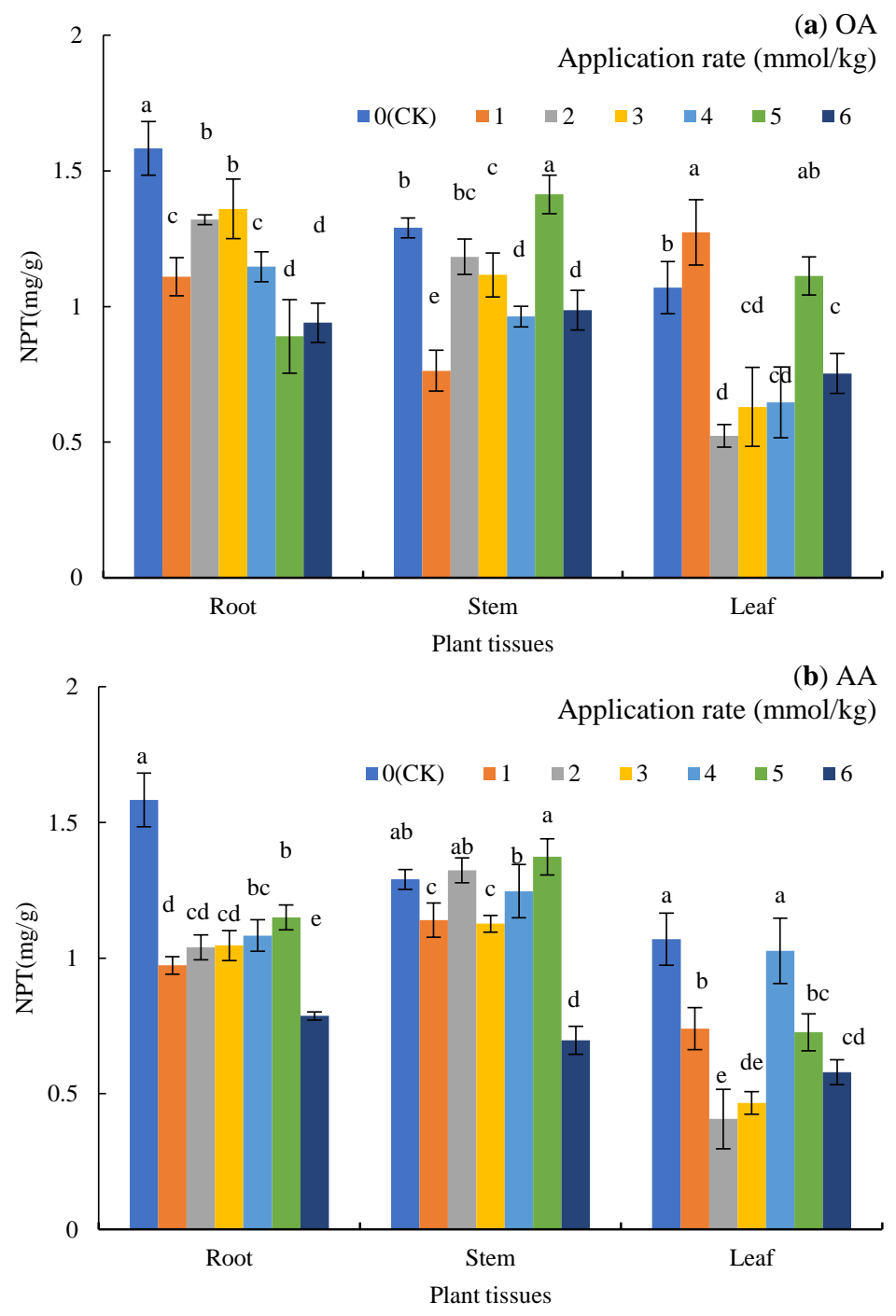

Figure 3. Cont. 

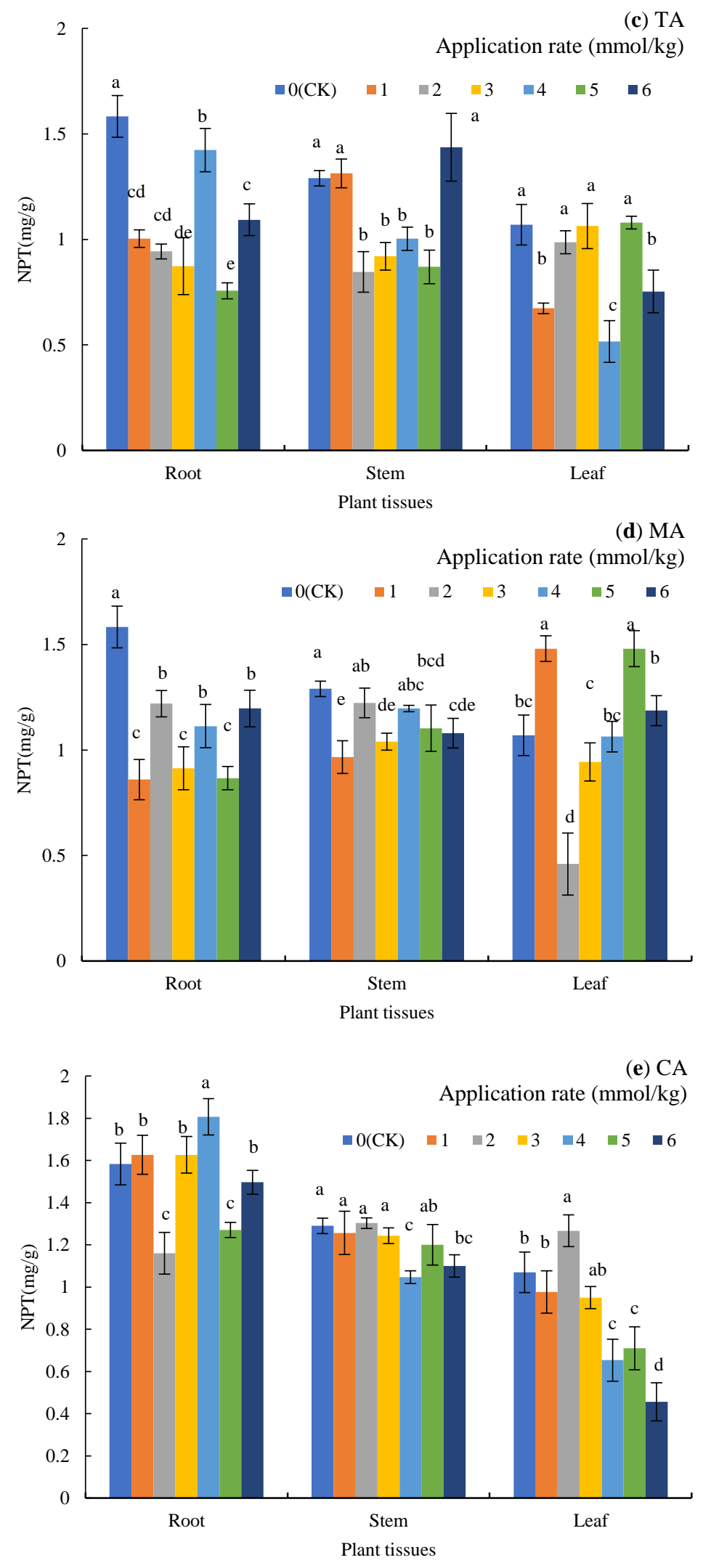

Figure 3. Nonprotein sulfhydryl (NPT) in the plant tissues under LMWOA treatments and the CK; (a) oxalic acid (OA), (b) acetic acid (AA), (c) tartaric acid (TA), (d) malic acid (MA), and (e) citric acid (CA). Different lowercase letters show significant differences for $p<0.05$. 
For AA (Figure 3b), the NPT content in the roots significantly decreased by $27.37-50.32 \%$ $(p<0.05)$, and the NPT content in the stems under the 1-5 mmol $/ \mathrm{kg}$ treatments was close to that of the CK, but the $6 \mathrm{mmol} / \mathrm{kg}$ treatment significantly decreased it by $45.99 \%(p<0.05)$. Except for the $4 \mathrm{mmol} / \mathrm{kg}$ treatment, the other treatments significantly reduced the NPT content in the leaves $(p<0.05)$.

The application of TA (Figure 3c) significantly reduced the NPT content in the roots by $10.11-52.21 \%(p<0.05)$, while the content of NPT in the stems under the $2-5 \mathrm{mmol} / \mathrm{kg}$ treatments significantly decreased by $22.22-34.37 \%(p<0.05)$. Additionally, the 1,4 , and $6 \mathrm{mmol} / \mathrm{kg}$ treatments significantly reduced NPT in the leaves by $37.07 \%, 51.71 \%$, and $29.60 \%$, respectively $(p<0.05)$.

The application of MA (Figure 3d) reduced the content of NPT in the roots (22.95-45.68\%) and the stems (5.17-25.06\%); except for the $2 \mathrm{mmol} / \mathrm{kg}$ treatment, the other treatments resulted in significant differences from the CK. NPT in the leaves increased by $38.32 \%$ and $38.32 \%(p<0.05)$ under the 1 and $5 \mathrm{mmol} / \mathrm{kg}$ treatments but decreased by $57.01 \%$ under the $2 \mathrm{mmol} / \mathrm{kg}$ treatment $(p<0.05)$.

When CA was applied (Figure 3e), NPT in the roots decreased by $26.74 \%$ and $19.79 \%$ $(p<0.05)$ under the 2 and $5 \mathrm{mmol} / \mathrm{kg}$ treatments, while NPT in the roots increased by $14.11 \%$ in the $4 \mathrm{mmol} / \mathrm{kg}$ treatment $(p<0.05)$. Compared to the CK, NPT in the stems decreased significantly under the 4 and $6 \mathrm{mmol} / \mathrm{kg}$ treatments $(p<0.05)$, while NPT in the leaves decreased by $38.94 \%, 33.64 \%$, and $57.32 \%$ under the 4,5 , and $6 \mathrm{mmol} / \mathrm{kg}$ treatments $(p<0.05)$.

\subsection{The Relationship between Soil Cd, Soil NPK, and Plant Cd}

Correlation analysis was performed on soil Cd, soil NPK, and plant Cd $(n=93$; Table 2). Root $\mathrm{Cd}$ had a significant negative correlation with stem and bud $\mathrm{Cd}(r=-0.340$ and -0.219 , respectively), and had a significant positive correlation with TP $(r=0.345)$. Stem $\mathrm{Cd}$ had a significant positive correlation with bud $\mathrm{Cd}$, Fe-Mn oxide $\mathrm{Cd}$, and TN $(r=0.648,0.306$, and 0.208 , respectively), and had a significant negative correlation with TP $(r=-0.208)$. Leaf $\mathrm{Cd}$ had a significant positive correlation with bud $\mathrm{Cd}$ and exchangeable $\mathrm{Cd}(r=0.291$ and 0.302 , respectively). Bud Cd had a significant positive correlation with Fe-Mn oxide $\mathrm{Cd}$ and Organic $\mathrm{Cd}(r=0.319$ and 0.239$)$. Soil total $\mathrm{Cd}$ had a significant positive correlation with exchangeable $\mathrm{Cd}$, carbonate $\mathrm{Cd}$, and Fe-Mn oxide $\mathrm{Cd}(r=0.373$, 0.397 , and 0.282). TP had a significant positive correlation with exchangeable $\mathrm{Cd}(\mathrm{r}=0.255)$ and a significant negative correlation with carbonate $\mathrm{Cd}$ and Fe-Mn oxide $\mathrm{Cd}(r=-0.219$ and -0.215$)$. AK had no significant correlation with soil $C d$ or plant $C d$. 
Table 2. The correlation coefficients between soil Cd, soil NPK, and plant Cd.

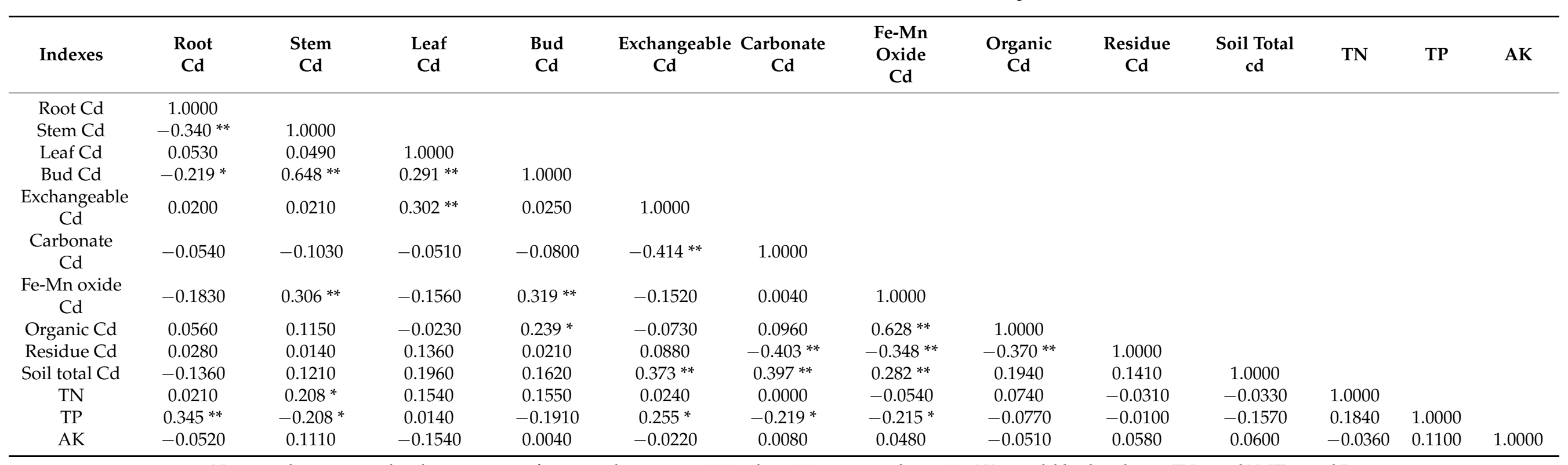




\section{Discussion}

\subsection{The Effect of Organic Acid on Plant Growth and Soil TN and TP}

Organic acids can promote the growth of sunflowers (Helianthus annuus Linn.), mainly in terms of increasing the plant height and the shoot biomass, which is consistent with the results of maize using citric and oxalic acids [49] and rapeseed using OA, CA, TA, MA, and AA [50]. OA, AA, and CA are beneficial for increasing the dry weight of the root system (Figure 1), which is mainly due to the increase in soil nitrogen and phosphorus content (Figure 4), especially the significant increase in TP. Under the action of plant root and soil water change, soil nutrients moved from nonrhizosphere to rhizosphere, increasing the TN and TP in rhizosphere soil [51-55]. Additionally, LMWOAs can be seen as a carbon source [56], which could promote the reproduction of soil microorganisms [57,58], resulting in an increased supply of soil $\mathrm{N}$ and $\mathrm{P}[59,60]$. In addition, the activities of urease, catalase, and alkaline phosphatase are increased by applying organic acids [57]. In addition, MA or AA application more or less reduces $\mathrm{Cd}$ phytotoxicity by increasing the growth parameters and photosynthetic pigment concentrations, by decreasing the accumulation of $\mathrm{H}_{2} \mathrm{O}_{2}$, and by improving the root activity [61], which can also promote crop growth.

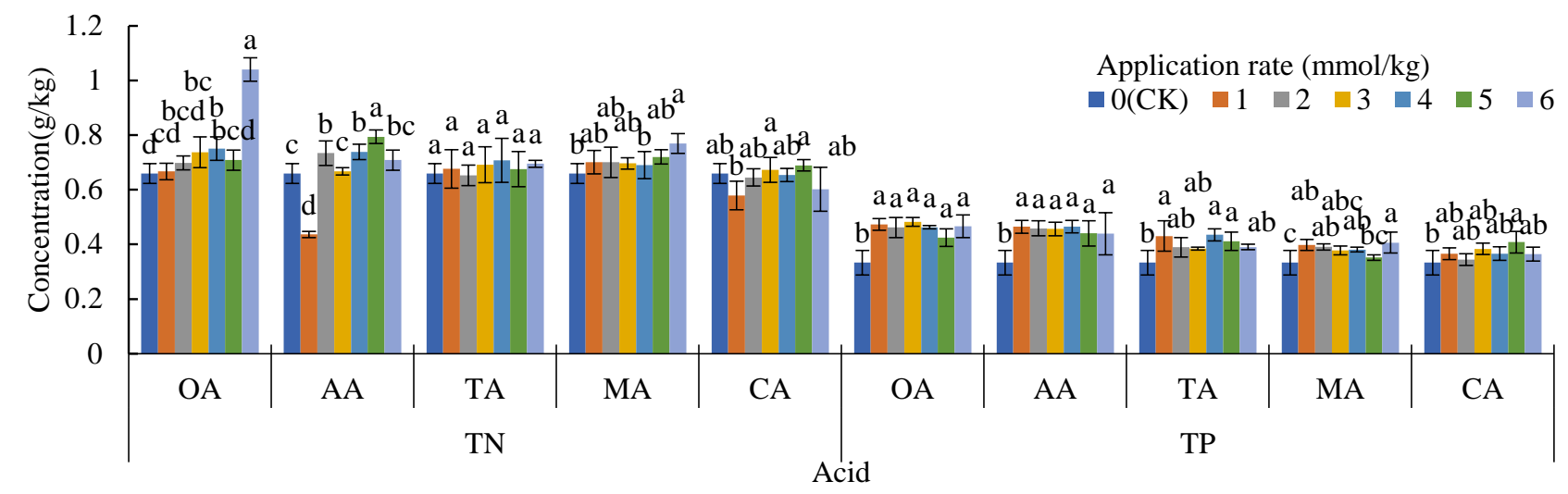

Figure 4. TN and TP in rhizosphere soil under organic treatments and CK; oxalic acid (OA), acetic acid (AA), tartaric acid (TA), malic acid (MA), and citric acid (CA). Different lowercase letters show significant differences for $p<0.05$.

Despite the fact that phosphorus and nitrogen were increased as the LMWOAs were applied [62], the effect of TP on dry matter accumulation was greater than that of TN. TP was closely related to exchangeable $\mathrm{Cd}$, carbon $\mathrm{Cd}$, Fe-Mn oxide $\mathrm{Cd}$, $\operatorname{root} \mathrm{Cd}$, and stem $\mathrm{Cd}$ (Table 2). As Table 3 shows, TN was positively correlated with plant biomass $(p>0.05)$, while TP was positively correlated with the biomass of the stems, leaves, shoots, and plants $(p<0.05)$. The addition of LMWOAs mainly increased the content of available phosphorus, and the LMWOAs had no significant effect on the content of hydrolytic nitrogen [63]. The amount of nitrogen applied in the experiment was higher than that of TP (see Section 2.1), resulting in the content of TN being higher than that of TP; therefore, nitrogen is sufficient or even excessive for plants, and at this point, the supply of phosphorus is critical $[64,65]$. Some low molecular organic acids (e.g., citric acid, tartaric acid, and acetic acid) can further increase the content of phosphate in soil through reducing the binding of phosphate ions to aluminum and iron [66].

Table 3. The correlation coefficients between TN, TP, and AK in the rhizosphere and plant biomass.

\begin{tabular}{ccccccc}
\hline Indexes & Root & Stem & Leaf & Bud & Shoot & Total Biomass \\
\hline TN & 0.135 & 0.082 & 0.069 & 0.007 & 0.073 & 0.081 \\
TP & 0.185 & $0.236^{*}$ & $0.235^{*}$ & 0.113 & $0.250^{*}$ & $0.250^{*}$ \\
AK & 0.002 & -0.044 & -0.014 & -0.06 & -0.045 & -0.042 \\
\hline
\end{tabular}

${ }^{*}$ represents a significant correlation at $p<0.05$. 


\subsection{The Effects of Organic Acids on Soil Cd}

Compared to the $\mathrm{CK}$, the application of organic acids increased the content of carbonate $\mathrm{Cd}$ and decreased the content of Fe-Mn oxide $\mathrm{Cd}$ (Figure 2), but the average exchangeable $\mathrm{Cd}$ of the other treatments also decreased, except for TA. The change of total $\mathrm{Cd}$ in the soil was mainly determined by these three forms of $\mathrm{Cd}$ (Table 2), which was similar to our previous research results on oil vegetables [43]. There were significant differences in the composition of the soil Cd forms between the LMWOA treatments and the CK-treated soil (the blue ellipse formed by A1, A2, and A3 is away from the other ellipses in Figure 5), and significant differences were also found among the different application rates of AA, MA, and CA (Figure 5). The transformation of Fe-Mn oxide $\mathrm{Cd}$ to other forms is the reason for the improvement in the bioavailability of $\mathrm{Cd}$. The driven dissolution of $\mathrm{Fe}$ and Mn by LMWOAs had a major control on the mobilization of Cd $[67,68]$. It can also be seen that the organic acids were able to change the form of $\mathrm{Cd}$ and improve the bioavailability of $\mathrm{Cd}$ (Figure 6a); it is beneficial for plants to absorb more $\mathrm{Cd}$. As Figure 5b shows, the plant $\mathrm{Cd}$ accumulations of OA, AA, TA, MA, and CA increased by $43.31 \%, 55.25 \%, 48.69 \%$, $0.52 \%$, and $32.94 \%$, respectively. The important reason for this is that organic acids can effectively activate the solid heavy metals adsorbed on the surface of soil particles and can transform said solid heavy metals into effective forms easily absorbed by plant roots [69].

The addition of acid did not significantly reduce $\mathrm{Cd}$ in rhizosphere soil; the mean reductions in $\mathrm{Cd}$ in soil for $\mathrm{OA}, \mathrm{AA}$, and CA increased by $1.72 \%, 3.54 \%$ and $8.38 \%$ compared to the CK, which for TA and MA decreased by $11.68 \%$ and $5.97 \%$, and even the 5 and $6 \mathrm{mmol} / \mathrm{kg}$ TA treatments significantly increased Cd (Figure 6c), indicating that the sunflowers mainly increased the root surface area to engage with more $\mathrm{Cd}$ [70] or increased $\mathrm{Cd}$ migration from nonrhizosphere soil to rhizosphere soil. In addition, it is not that a higher application rate of organic acids results in better remediation of $\mathrm{Cd}$ in soil, because the toxicity of $\mathrm{Cd}$ increases with an increase in the concentration of low molecular weight organic acids [71]. For example, the $6 \mathrm{mmol} / \mathrm{kg}$ OA, TA, CA, and AA treatments reduced NPT in the roots, stems, and leaves (Figure 3 ), which is not conducive to maintaining a high Cd content in plant tissues.

\subsection{Organic Acids Are Beneficial to the Cd Detoxification of Plants}

The application of organic acids significantly reduced the NPT content in the roots, but the effect on the NPT content in the stems and leaves changed with the application rates (Figure 3). In full, the NPT content in the roots was higher than that in the stems and leaves, which is consistent with the $\mathrm{Cd}$ content in the roots, stems, and leaves (the average $\mathrm{Cd}$ contents in the roots, stems, and leaves were $36.6,7.22$, and $12.95 \mathrm{mg} / \mathrm{kg}$ ). NPT plays an important role in the tolerance and detoxification of $\mathrm{Cd}$ in plants, which can be complexed with excessive Cd [72-74].

We found that there was a high correlation between $\mathrm{Cd}$ and NPT in the roots; with the increase in root Cd content, NPT also showed an increasing trend. Except for CA, the $R^{2}$ of the fitting linear equation of other acids was greater than 0.39 (Figure S1). There was no significant increase or decrease in the NPT content of the stems and leaves as the $\mathrm{Cd}$ in the stems and leaves changed, which is different from the results of Posidonia oceanica L. [75]. NPT contains glutathione (GSH) and other NPT compounds (plant chelating peptide (PC), cysteine (Cys), etc.). The contributed NPT compounds react differently to the detoxification of Cd in different plants, such as maize [76], Arabis paniculata Franch [77], Eichhornia crassipes [78], and different plant tissues [79,80]. Not all of the PCs induced by Cd were involved in the detoxification of Cd [32] and the change trend of NPT and GSH in the leaves may be opposite under $\mathrm{Cd}$ stress [81] or in different growth stages [82]. Therefore, further analysis of GSH, PC, and Cys is needed. 

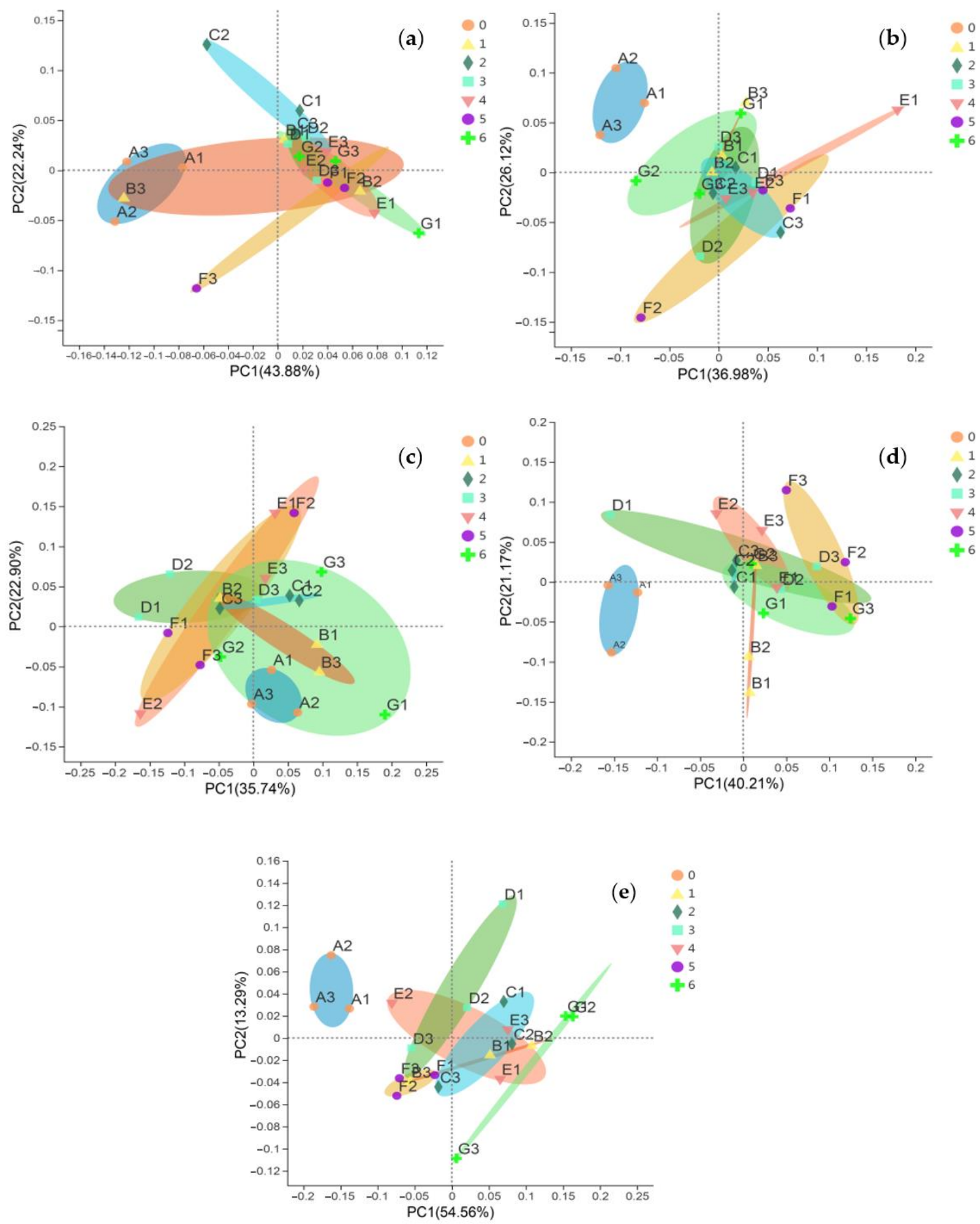

Figure 5. Principal co-ordinates analysis (PCoA) on the soil $\mathrm{Cd}$ forms of the organic treatments and the $\mathrm{CK}(0 \mathrm{mmol} / \mathrm{kg})$; (a) oxalic acid (OA), (b) acetic acid (AA), (c) tartaric acid (TA), (d) malic acid (MA), and (e) citric acid (CA). A1, A2, and A3 are the three samples of $\mathrm{CK}(0 \mathrm{mmol} / \mathrm{kg}) ; \mathrm{B} 1, \mathrm{~B} 2$, and B3 are the three samples of $1 \mathrm{mmol} / \mathrm{kg} ; \mathrm{C} 1, \mathrm{C} 2$, and C3 are the three samples of $2 \mathrm{mmol} / \mathrm{kg}$; D1, D2, and D3 are the three samples of $3 \mathrm{mmol} / \mathrm{kg}$; E1, E2, and E3 are the three samples of $4 \mathrm{mmol} / \mathrm{kg}$; F1, F2, and F3 are the three samples of $5 \mathrm{mmol} / \mathrm{kg} ; \mathrm{G} 1, \mathrm{G} 2$, and G3 are the three samples of $6 \mathrm{mmol} / \mathrm{kg}$. 

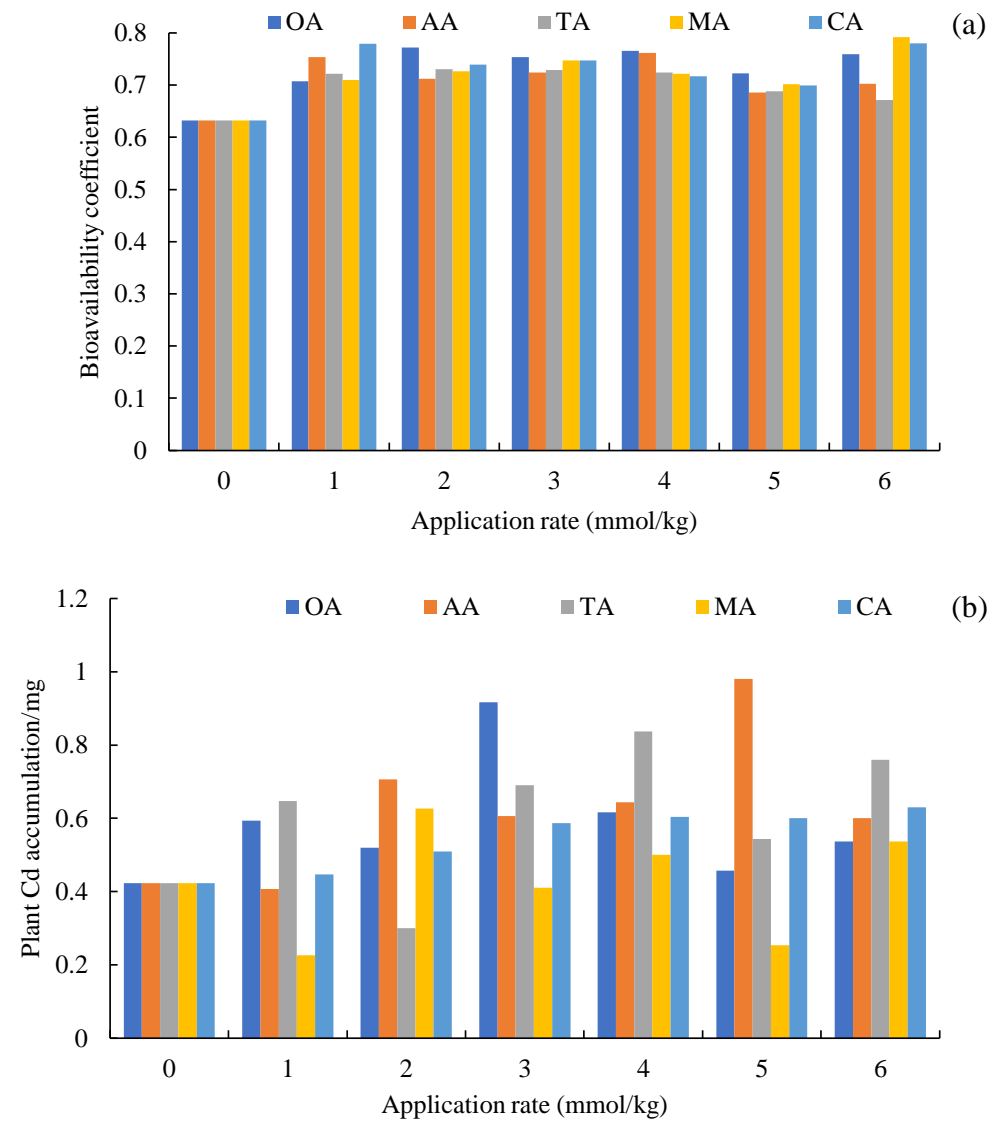

(b)

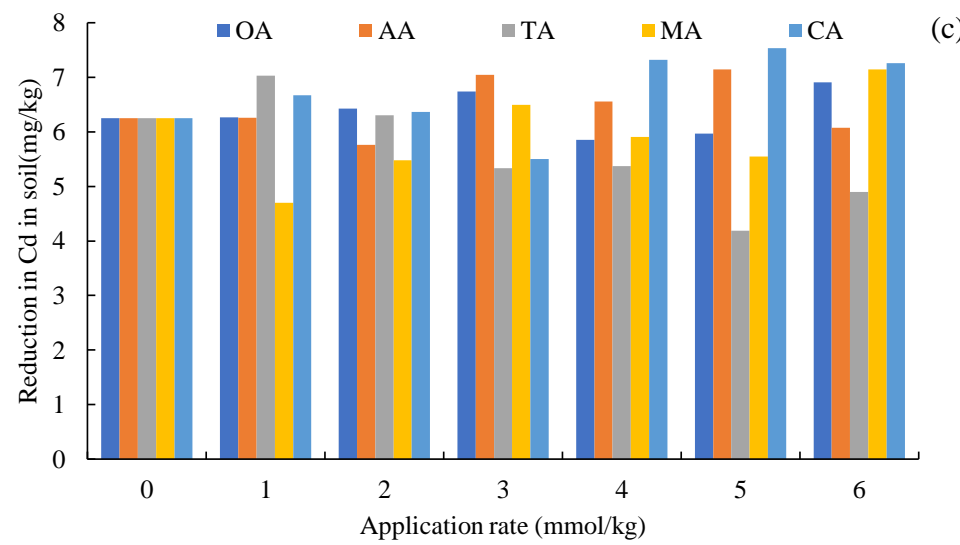

Figure 6. Bioavailability coefficient (a), plant $\mathrm{Cd}$ accumulation (b), and reduction in $\mathrm{Cd}$ in the soil (c) with the organic acids and their application rates, along with the CK $(0 \mathrm{mmol} / \mathrm{kg})$ - oxalic acid $(\mathrm{OA})$, acetic acid (AA), tartaric acid (TA), malic acid (MA), and citric acid (CA).

NPT is helpful for Cd migration from roots to shoots [83,84], reducing the toxicity of $\mathrm{Cd}$ to roots [79]. Increasing the toxicity of $\mathrm{Cd}$ to shoots is not conducive to improving the efficiency of the phytoremediation of heavy metals. In our experiment, NPT in the stems and leaves showed a negative correlation with the biomass of said stems and leaves (Figure S2), indicating that a decrease in NPT was beneficial to biomass accumulation. The reason for this is that $\mathrm{OA}, \mathrm{AA}, \mathrm{TA}$, and $\mathrm{CA}$ significantly reduced the migration of $\mathrm{Cd}$ from the roots to shoots (Table S1), but NPT in the shoots did not change with the content of $\mathrm{Cd}$ and weakened the toxic effect of $\mathrm{Cd}$ on the shoots, which was conducive to maintaining the strong photosynthetic capacity of the plants and accumulating more dry matter [85]. Although the content of $\mathrm{Cd}$ in the shoots did not increase significantly, the dry matter in the 
shoots increased dramatically (Figure 1), which led to an increase in the Cd accumulation in the shoots (Figure 6).

The purpose of phytoremediation is to increase the quality of soil and serve human beings [86], which is not only reflected in the removal of soil pollution, but also can bring income in the process of phytoremediation, such as selling the thallium from phytoremediation [87]. Although there is a two-way relationship between tourism and Cd pollution [88], for polluted land, combining agriculture with tourism is a benefit to save the cost of soil remediation, as sunflowers are very beautiful (Figure S3), which were introduced as new crops for enhancing rural landscape [89]. We could reduce the persecution of heavy metals on sunflower by applying LMWOAs and $\mathrm{Cd}$ accumulation. The order of maximum $\mathrm{Cd}$ accumulation was $\mathrm{AA}>\mathrm{OA}>\mathrm{TA}>\mathrm{CA}>\mathrm{MA}$, but the corresponding application rate was different. Additionally, the $\mathrm{Cd}$ accumulation changed in a wave shape with different application rates. The effects of organic acids on heavy metals in soil are twofold, mainly depending on the concentration and types of organic acids, the forms of heavy metals, the soil quality, and action the environment [90], through influencing the complexing ability of Cd with organic acids [91]. There is evidence that LMTOAs have different effects on the transfer of heavy metals from soil to vegetables [16]: MA is more effective in the alleviation of $\mathrm{Cd}$ stress in sunflowers than AA, because MA diminishes $\mathrm{Cd}$ toxicity by enhancing root activity and reducing $\mathrm{H}_{2} \mathrm{O}_{2}$ levels [92]. Meanwhile, $\mathrm{OA}$ was the only acid effective in increasing the metal micronutrients at the lowest $\mathrm{Pb}$ level, and citric acid was not at the highest $\mathrm{Pb}$ level [49]. Based on the above results, for specific soil and different crops, it is necessary to select suitable organic acids to promote phytoremediation.

\section{Conclusions}

The five investigated LMWOAs (i.e., OA, AA, TA, MA, and CA) had positive effects on the bioavailability coefficient of $\mathrm{Cd}$ in the soil. After the application of the LMWOAs, the main toxic effect of $\mathrm{Cd}$ on the plants was on the roots. NPT in the roots increased with the increase in root $\mathrm{Cd}$ content, but the $\mathrm{OA}, \mathrm{AA}, \mathrm{TA}$, and $\mathrm{CA}$ reduced the transfer coefficient of $\mathrm{Cd}$ from the roots to the stems and leaves; however, they also weakened the toxic effect on the stems and leaves, manifested as a lack of a correlation with the $\mathrm{Cd}$ and NPT content of the stems and leaves. This effect helped to maintain normal development aboveground, while the increased supply of $\mathrm{N}$ and $\mathrm{P}$ in the soil further promoted the growth of the sunflowers, especially the shoot biomass, which was increased by $59.18 \%$, $66.36 \%, 66.92 \%, 11.23 \%$ and $63.34 \%$ for OA, AA, TA, MA, and CA treatments, respectively. TP played a more important role in the change of $\mathrm{Cd}$ in the soil and plant tissues than TN. Although application of the LMWOAs did not significantly reduce $\mathrm{Cd}$ in rhizosphere soil (the reduction in Cd in soil for OA, AA, and CA increased by $1.72 \%, 3.54 \%$ and 8.38 compared to the CK, which decreased for TA and MA by $11.68 \%$ and $5.97 \%$ ), it significantly increased the aboveground dry matter quality of the oil sunflowers and increased the $\mathrm{Cd}$ accumulation of plants.

Supplementary Materials: The following are available online at https:/ /www.mdpi.com/2075-163 X/11/3/243/s1: Figure S1: Linear fitting results of NPT and Cd in roots under 1-6 $\mathrm{mmol} / \mathrm{kg}$ organic acid treatments; Figure S2: Linear fitting results of the NPT content and biomass of roots (a), stems (b), and leaves (c); Figure S3: Sunflower during experiment period; Table S1: The transport factor (TF) and bioconcentration factor (BF) of different plant tissues.

Author Contributions: Conceptualization, D.Q.; Methodology, H.L.; Software, H.L.; Formal analysis, H.L.; Investigation, Y.H., F.B. and Y.Z.; Resources, Y.W. and F.B.; Data curation, Y.H. and F.B.; Writing—original draft preparation, H.L.; Writing—review and editing, D.Q.; Supervision, D.Q.; Project administration, D.Q. and Y.W.; Funding acquisition, D.Q. All authors have read and agreed to the published version of the manuscript.

Funding: This research was funded by Program of the National Natural Science Foundation of China (51879268), Key Research and Development and Promotion Projects of Henan Province (212400410790), Natural Science Foundation of Henan Province (212300410139). 
Institutional Review Board Statement: Not applicable.

Informed Consent Statement: Not applicable.

Data Availability Statement: Not applicable.

Acknowledgments: We greatly thank all anonymous reviewers for their constructive comments, which improved the manuscript.

Conflicts of Interest: The authors declare no conflict of interest.

\section{References}

1. Sowana, A.; Shrestha, R.P.; Parkpian, P.; Pongquan, S. Influence of coastal land use on soil heavy-metal contamination in pattani bay, thailand. J. Coast. Res. 2011, 27, 252-262. [CrossRef]

2. Nikolic, N.; Nikolic, M. Gradient analysis reveals a copper paradox on floodplain soils under long-term pollution by mining waste. Sci. Total Environ. 2012, 425, 146-154. [CrossRef]

3. Savic, R.; Ondrasek, G.; Josimov-Dundjerski, J. Heavy metals in agricultural landscapes as hazards to human and ecosystem health: A case study on zinc and cadmium in drainage channel sediments. J. Sci. Food Agric. 2015, 95, 466-470. [CrossRef] [PubMed]

4. Awofolu, O.R.; Mbolekwa, Z.; Mtshemla, V.; Fatoki, O.S. Levels of trace metals in water and sediment from tyume river and its effects on an irrigated farmland. Water 2005, 31, 87-94. [CrossRef]

5. Zhuang, S.K.; Lu, X.W. Environmental risk evaluation and source identification of heavy metal(loid)s in agricultural soil of shangdan valley, northwest china. Sustainability 2020, 12, 5806. [CrossRef]

6. $\quad$ Chen, Q.W.; Dong, J.W.; Yi, Q.T.; Liu, X.L.; Zhang, J.Y.; Zeng, Z.X. Proper mode of using rice straw biochar to treat cd-contaminated irrigation water in mining regions based on a multiyear in situ experiment. ACS Sustain. Chem. Eng. 2019, 7, 9928-9936. [CrossRef]

7. Ahmad, K.; Wajid, K.; Khan, Z.I.; Ugulu, I.; Memoona, H.; Sana, M.; Nawaz, K.; Malik, I.S.; Bashir, H.; Sher, M. Evaluation of potential toxic metals accumulation in wheat irrigated with wastewater. Bull. Environ. Contam. Toxicol. 2019, 102, 822-828. [CrossRef] [PubMed]

8. Haroon, B.; Ping, A.; Pervez, A.; Faridullah, F.; Irshad, M. Characterization of heavy metal in soils as affected by long-term irrigation with industrial wastewater. J. Water Reuse Desalin. 2019, 9, 47-56. [CrossRef]

9. Anyanwu, E.D.; Nwachukwu, E.D. Heavy metal content and health risk assessment of a south-eastern nigeria river. Appl. Water Sci. 2020, 10, 1-9. [CrossRef]

10. Shang, D.; Geissler, B.; Mew, M.; Satalkina, L.; Zenk, L.; Tulsidas, H.; Barker, L.; El-Yahyaoui, A.; Hussein, A.; Taha, M.; et al. Unconventional uranium in china's phosphate rock: Review and outlook. Renew. Sustain. Energy Rev. 2021, 140, 110740. [CrossRef]

11. Lin, H.; Liu, C.; Li, B.; Dong, Y. Trifolium repens 1. Regulated phytoremediation of heavy metal contaminated soil by promoting soil enzyme activities and beneficial rhizosphere associated microorganisms. J. Hazard. Mater. 2021, 402, 123829. [CrossRef] [PubMed]

12. Zine, H.; Elgadi, S.; Hakkou, R.; Papazoglou, E.; Midhat, L.; Ahmed, O. Wild plants for the phytostabilization of phosphate mine waste in semi-arid environments: A field experiment. Minerals 2020, 11, 42. [CrossRef]

13. Zhang, X.; Zhang, Y.; Liu, X.; Zhang, C.; Dong, S.; Liu, Q.; Deng, M. Cd uptake by phytolacca americana l. Promoted by cornstalk biochar amendments in cd-contaminated soil. Int. J. Phytoremediation 2020, 22, 251-258. [CrossRef] [PubMed]

14. Parzentny, H.R.; Róg, L. Distribution and mode of occurrence of co, ni, cu, zn, as, ag, cd, sb, pb in the feed coal, fly ash, slag, in the topsoil and in the roots of trees and undergrowth downwind of three power stations in poland. Minerals 2021, 11, 133. [CrossRef]

15. Yu, G.; Liu, J.; Long, Y.; Chen, Z.; Sunahara, G.I.; Jiang, P.; You, S.; Lin, H.; Xiao, H. Phytoextraction of cadmium-contaminated soils: Comparison of plant species and low molecular weight organic acids. Int. J. Phytoremed. 2020, 22, 383-391. [CrossRef]

16. Wang, Z.W.; Wang, W.Z.; Wang, Z.L.; Liu, Y.M.; Ma, M.H.; Wu, J. Impact of a long-term cultivation on low molecular weight organic acids in greenhouse soil and their influence on vegetable uptake heavy metals. Soil Sediment Contam. 2021, 30, 1-11. [CrossRef]

17. Zalesny, R.S.; Bauer, E.O. Evaluation of populus and salix continuously irrigated with landfill leachate ii. Soils and early tree development. Int. J. Phytoremed. 2007, 9, 307-323. [CrossRef]

18. da Silva, M.; de Andrade, S.A.L.; De-Campos, A.B. Phytoremediation potential of jack bean plant for multi-element contaminated soils from ribeira valley, brazil. Clean-Soil Air Water 2018, 46, 1700321. [CrossRef]

19. Rezapour, S.; Atashpaz, B.; Moghaddam, S.S.; Damalas, C.A. Heavy metal bioavailability and accumulation in winter wheat (triticum aestivum 1.) irrigated with treated wastewater in calcareous soils. Sci. Total Environ. 2019, 656, 261-269. [CrossRef]

20. Raza, A.; Habib, M.; Kakavand, S.N.; Zahid, Z.; Zahra, N.; Sharif, R.; Hasanuzzaman, M. Phytoremediation of cadmium: Physiological, biochemical, and molecular mechanisms. Biology 2020, 9, 177. [CrossRef] [PubMed]

21. Yan, X.; Wang, J.Q.; Song, H.C.; Peng, Y.J.; Zuo, S.H.; Gao, T.C.; Duan, X.X.; Qin, D.; Dong, J.Y. Evaluation of the phytoremediation potential of dominant plant species growing in a chromium salt-producing factory wasteland, china. Environ. Sci. Pollut. Res. 2020, 27, 7657-7671. [CrossRef] [PubMed] 
22. Singh, G.; Pankaj, U.; Ajayakumar, P.V.; Verma, R.K. Phytoremediation of sewage sludge by cymbopogon martinii (roxb.) wats. Var. Motia burk. Grown under soil amended with varying levels of sewage sludge. Int. J. Phytoremed. 2020, 22, 540-550. [CrossRef] [PubMed]

23. Agnello, A.C.; Huguenot, D.; Van Hullebusch, E.D.; Esposito, G. Enhanced phytoremediation: A review of low molecular weight organic acids and surfactants used as amendments. Crit. Rev. Environ. Sci. Technol. 2014, 44, 2531-2576. [CrossRef]

24. Huang, R.; Dong, M.L.; Mao, P.; Zhuang, P.; Paz-Ferreiro, J.; Li, Y.X.; Li, Y.W.; Hu, X.Y.; Netherway, P.; Li, Z.A. Evaluation of phytoremediation potential of five cd (hyper)accumulators in two cd contaminated soils. Sci. Total Environ. 2020, 721, 137581. [CrossRef] [PubMed]

25. Duarte, B.; Freitas, J.; Caçador, I. The role of organic acids in assisted phytoremediation processes of salt marsh sediments. Hydrobiologia 2011, 674, 169-177. [CrossRef]

26. Zhang, H.J.; Lu, T.T.; Shang, Z.B.; Li, Y.X.; He, J.Y.; Liu, S.H.; Li, D.L.; Zhou, Y.M.; Qi, Z.C. Transport of cd ${ }^{2+}$ through saturated porous media: Insight into the effects of low-molecular-weight organic acids. Water Res. 2020, 168, 115182. [CrossRef]

27. Suherman; Rachmanda, A.M.; Roto; Morita, K. Effect of low molecular weight organic acid (lmwoa) on the $\mathrm{zn}^{2+}$ desorption from the soil of illegal land fill in yogyakarta-indonesia. In Proceedings of the 14th Joint Conference on Chemistry 2019, Surakarta, Indonesia, 10-11 September 2019; Rahmawati, F., Saraswati, T.E., Nugrahaningtyas, K.D., Marliyana, S.D., Kusumaningsih, T., Eds.; AIP Publishing LLC.: Melville, NY, USA, 2020; Volume 2237.

28. Geng, H.H.; Wang, F.; Yan, C.C.; Tian, Z.J.; Chen, H.L.; Zhou, B.H.; Yuan, R.F.; Yao, J. Leaching behavior of metals from iron tailings under varying ph and low-molecular-weight organic acids. J. Hazard. Mater. 2020, 383, 121136. [CrossRef] [PubMed]

29. Ghasemi-Fasaei, R.; Paridar, Z.; Ronaghi, A. The role of low molecular weight organic acids in release kinetics of zinc and cadmium in polluted calcareous soil in the presence of fish scales derivatives. Chem. Ecol. 2020, 1-4. [CrossRef]

30. Mahimairaja, N.S.B.R.N.; Baskaran, S. Influence of low-molecular-weight organic acids on the solubilization of phosphates. Biol. Fertil. Soils 1994, 18, 311-319.

31. Song, W.-Y.; Mendoza Cozatl, D.; Lee, Y.; Schroeder, J.; Ahn, S.-N.; Lee, H.-S.; Wicker, T.; Martinoia, E. Phytochelatin-metal(loid) transport into vacuoles shows different substrate preferences in barley and arabidopsis. Plant Cell Environ. 2013, 37, 1192-1201. [CrossRef] [PubMed]

32. Wei, Z.; Wong, J.W.; Chen, D. Speciation of heavy metal binding non-protein thiols in agropyron elongatum by size-exclusion hplc-icp-ms. Microchem. J. 2003, 74, 207-213. [CrossRef]

33. Sangman, L.; Jae, S.M.; Tae-Seok, K.; David, P.; Goldsbrough, P.B.; Schuyler, S.K. Overexpression of arabidopsis phytochelatin synthase paradoxically leads to hypersensitivity to cadmium stress. Plant Physiol. 2003, 131, 656-663.

34. Alloway, B. Heavy Metals in Soils: Trace Metals and Metalloids in Soils and Their Bioavailability; Springer: Dordrecht, The Netherlands, 2013.

35. Oral, A.; Uygur, V. Effects of low-molecular-mass organic acids on p nutrition and some plant properties of hordeum vulgare. J. Plant Nutr. 2018, 41, 1482-1490. [CrossRef]

36. Johansen, S.L.; Sivasothy, A.; Dowd, M.K.; Reilly, P.J.; Hammond, E.G. Low-molecular weight organic compositions of acid waters from vegetable oil soapstocks. J. Am. Oil Chem. Soc. 1996, 73, 1275-1286. [CrossRef]

37. Goksoy, A.T.; Demir, A.O.; Turan, Z.M.; Dagustu, N. Responses of sunflower (helianthus annus 1.) to full and limited irrigation at different growth stages. Field Crop. Res. 2004, 87, 167-178. [CrossRef]

38. Zehra, A.; Sahito, Z.A.; Tong, W.B.; Tang, L.; Hamid, Y.; Wang, Q.; Cao, X.R.; Khan, M.B.; Hussain, B.; Jatoi, S.A.; et al. Identification of high cadmium-accumulating oilseed sunflower (helianthus annuus) cultivars for phytoremediation of an oxisol and an inceptisol. Ecotoxicol. Environ. Saf. 2020, 187, 109857. [CrossRef] [PubMed]

39. Zhou, J.; Chen, L.H.; Peng, L.; Luo, S.; Zeng, Q.R. Phytoremediation of heavy metals under an oil crop rotation and treatment of biochar from contaminated biomass for safe use. Chemosphere 2020, 247, 125856. [CrossRef]

40. Benavides, B.J.; Drohan, P.J.; Spargo, J.T.; Maximova, S.N.; Guiltinan, M.J.; Miller, D.A. Cadmium phytoextraction by helianthus annuus (sunflower), brassica napus cv wichita (rapeseed), and chyrsopogon zizanioides (vetiver). Chemosphere 2021, $265,129086$. [CrossRef]

41. Chen, L.; Hu, W.-F.; Long, C.; Wang, D. Exogenous plant growth regulator alleviate the adverse effects of $\mathrm{u}$ and cd stress in sunflower (helianthus annuus 1.) and improve the efficacy of $u$ and cd remediation. Chemosphere 2021, 262, 127809. [CrossRef] [PubMed]

42. Jiang, Y.; Ruan, X.; Ma, J. Heavy metal pollution and classification management of sewage irrigation farmland around a battery factory in xinxiang, henan province. Acta Sci. Circumstantiae 2020, 40, 645-654.

43. Qiao, D.; Lu, H.; Zhang, X. Change in phytoextraction of cd by rapeseed (brassica napus 1.) with application rate of organic acids and the impact of cd migration from bulk soil to the rhizosphere. Environ. Pollut. 2020, 267, 115452. [CrossRef]

44. Ma, H.; Li, X.; Hou, S.; Peng, D.; Wang, Y.; Xu, F.; Xu, H. The activation and extraction systems using organic acids and lentinus edodes to remediate cadmium contaminated soil. Environ. Pollut. 2019, 255, 113252. [CrossRef] [PubMed]

45. Rama Devi, S.; Prasad, M.N.V. Copper toxicity in ceratophyllum demersum 1. (coontail), a free floating macrophyte: Response of antioxidant enzymes and antioxidants. Plant Sci. 1998, 138, 157-165. [CrossRef]

46. He, Q.; Wu, Y.; Bing, H.; Zhou, J.; Wang, J. Vegetation type rather than climate modulates the variation in soil enzyme activities and stoichiometry in subalpine forests in the eastern tibetan plateau. Geoderma 2020, 374, 114424. [CrossRef] 
47. Xu, Y.; Wang, X.; Bai, J.; Wang, D.; Wang, W.; Guan, Y. Estimating the spatial distribution of soil total nitrogen and available potassium in coastal wetland soils in the yellow river delta by incorporating multi-source data. Ecol. Indic. 2020, 111, 106002. [CrossRef]

48. Tessier, A.; Campbell, P.G.; Bisson, M. Sequential extraction procedure for the speciation of particulate trace metals. Anal. Chem. 1979, 51, 844-851. [CrossRef]

49. Metanat, K.; Ghasemi-Fasaei, R.; Ronaghi, A.; Yasrebi, J. Lead phytostabilization and cationic micronutrient uptake by maize as influenced by pb levels and application of low molecular weight organic acids. Commun. Soil Sci. Plant Anal. 2019, 50, 1887-1896. [CrossRef]

50. Lu, H.; Qiao, D.; Qi, X.; Hu, C.; Zhao, Z.; Bai, F.; Zhao, Y.; Han, Y. Effects of exogenous organic acids on soil ph, enzyme activity, and cadmium migration and transformation. J. Agro-Environ. Sci. 2020, 39, 542-553.

51. Kumar, V.; Ghosh, B.C.; Bhat, R.; Karmakar, S. Effect of irrigation and fertilizer on yield, water-use efficiency and nutrient uptake of summer groundnut (arachis hypogaea). Indian J. Agron. 2000, 45, 756-760.

52. Pietola, L.; Salo, T. Response of $\mathrm{p}, \mathrm{k}, \mathrm{mg}$ and no3-n contents of carrots to irrigation, soil compaction, and nitrogen fertilisation. Agric. Food Sci. Finl. 2000, 9, 319-331. [CrossRef]

53. Guo, A.; Zhao, Z.; Zhang, P.; Yang, Q.; Li, Y.; Wang, G. Linkage between soil nutrient and microbial characteristic in an opencast mine, china. Sci. Total Environ. 2019, 671, 905-913. [CrossRef] [PubMed]

54. Azam, H.M.; Alam, S.T.; Hasan, M.; Yameogo, D.D.S.; Kannan, A.D.; Rahman, A.; Kwon, M.J. Phosphorous in the environment: Characteristics with distribution and effects, removal mechanisms, treatment technologies, and factors affecting recovery as minerals in natural and engineered systems. Environ. Sci. Pollut. Res. 2019, 26, 20183-20207. [CrossRef]

55. Qiu, Q.; Li, J.; Wang, J.; Wang, N.; Sun, K.; He, Q.; Su, Y.; Pan, X. Microbes, enzyme activities and nutrient characteristics of rhizosphere and nonrhizosphere soils under four shrubs in xining nanshan, prefecture, china. Acta Ecol. Sin. 2014, 34, 7411-7420.

56. Huang, G.; You, J.; Zhou, X.; Ren, C.; Islam, M.S.; Hu, H. Effects of low molecular weight organic acids on cu accumulation by castor bean and soil enzyme activities. Ecotoxicol. Environ. Saf. 2020, 203, 110983. [CrossRef] [PubMed]

57. Hu, T.; Sørensen, P.; Olesen, J. Soil carbon varies between different organic and conventional management schemes in arable agriculture. Eur. J. Agron. 2018, 94, 79-88. [CrossRef]

58. Bai, J.; Tan, C.; Cao, X.; Zhou, Q.; Huang, S.; Peng, X.; Deng, Y.; Sun, L. Effect of three organic acids on the remediation efficiency of sedum plumbizincicola and soil microbial quantity. J. Soil Water Conserv. 2020, 34, 318-324.

59. Hu, H.; Cheng, Y.; Ma, Y.; Yu, X.; Xiang, J. Decomposition characteristics of returned rapeseed straw in soil and effects on soil fertility. Chin. J. Eco-Agric. 2012, 20, 297-302. [CrossRef]

60. Gyaneshwar, P.; Kumar, G.; Parekh, L.; Poole, P. Role of soil microorganisms in improving p nutrition of plants. Plant Soil 2002, 245, 83-93. [CrossRef]

61. Hawrylak-Nowak, B.; Dresler, S.; Matraszek, R. Exogenous malic and acetic acids reduce cadmium phytotoxicity and enhance cadmium accumulation in roots of sunflower plants. Plant Physiol. Biochem. 2015, 94, 225-234. [CrossRef] [PubMed]

62. Ma, H.; Li, X.; Wei, M.; Zeng, G.; Hou, S.; Li, D.; Xu, H. Elucidation of the mechanisms into effects of organic acids on soil fertility, cadmium speciation and ecotoxicity in contaminated soil. Chemosphere 2020, 239, 124706. [CrossRef] [PubMed]

63. Zhao, P.; Chen, X.; Yang, X.; Qi, S.; Wang, E. Relationship between enzyme activities and nutrients of black soil subjected to low molecular organic acid. J. Nanjing For. Univ. (Nat. Sci. Ed.) 2018, 42, 105-112.

64. Perring, M.; Hedin, L.; Levin, S.; McGroddy, M.; de Mazancourt, C. Increased plant growth from nitrogen addition should conserve phosphorus in terrestrial ecosystems. Proc. Natl. Acad. Sci. USA 2008, 105, 1971-1976. [CrossRef] [PubMed]

65. Latasa, M.; Berdalet, E. Effect of nitrogen or phosphorus starvation on pigment composition of cultured heterocapsa sp. J. Plankton Res. 1994, 16, 83-94. [CrossRef]

66. Earl, K.; Syers, J.; Mclaughlin, J. Origin of the effects of citrate, tartrate, and acetate on phosphate sorption by soils and synthetic gels1. Soil Sci. Soc. Am. J. 1979, 43, 674-678. [CrossRef]

67. Qin, J.; Enya, O.; Lin, C. Dynamics of fe, $\mathrm{mn}$, and al liberated from contaminated soil by low-molecular-weight organic acids and their effects on the release of soil-borne trace elements. Appl. Sci. 2018, 8, 2444. [CrossRef]

68. Nworie, O.; Qin, J.; Lin, C. Differential effects of low-molecular-weight organic acids on the mobilization of soil-borne arsenic and trace metals. Toxics 2017, 5, 18. [CrossRef] [PubMed]

69. Passatore, L.; Rossetti, S.; Juwarkar, A.A.; Massacci, A. Phytoremediation and bioremediation of polychlorinated biphenyls (pcbs): State of knowledge and research perspectives. J. Hazard. Mater. 2014, 278, 189-202. [CrossRef] [PubMed]

70. Rees, F.; Sterckeman, T.; Morel, J.L. Root development of non-accumulating and hyperaccumulating plants in metal-contaminated soils amended with biochar. Chemosphere 2016, 142, 48-55. [CrossRef]

71. Liao, M.; Huang, C. Effects of organic acids on the toxicity of cadmium during ryegrass growth. Chin. J. Appl. Ecol. 2002, 13, 109-112.

72. Domínguez-Solís, J.; López-Martín, M.; Ager, F.J.; Ynsa, M.; Romero, L.; Gotor, C. Increased cysteine availability is essential for cadmium tolerance and accumulation in arabidopsis thaliana. Plant Biotechnol. J. 2004, 2, 469-476. [CrossRef] [PubMed]

73. Sun, Q.; Ye, Z.H.; Wang, X.R.; Wong, M.H. Increase of glutathione in mine population of sedum alfredii: A zn hyperaccumulator and pb accumulator. Phytochemistry 2005, 66, 2549-2556. [CrossRef] [PubMed] 
74. Pomponi, M.; Censi, V.; Di Girolamo, V.; De Paolis, A.; di Toppi, L.S.; Aromolo, R.; Costantino, P.; Cardarelli, M. Overexpression of arabidopsis phytochelatin synthase in tobacco plants enhances $\mathrm{cd}^{2+}$ tolerance and accumulation but not translocation to the shoot. Planta 2006, 223, 180-190. [CrossRef]

75. Maserti, B.E.; Ferrillo, V.; Avdis, O.; Nesti, U.; Garbo, A.D.; Catsiki, A.; Maestrini, P.L. Relationship of non-protein thiol pools and accumulated cd or hg in the marine macrophyte posidonia oceanica (1.) delile. Aquat. Toxicol. 2005, 75, 288-292. [CrossRef]

76. Hou, M.; Huo, Y.; Zhang, Z.; Wei, M. Effects of exogenous vanadium stress on vanadium accumulation and subcellular distribution, and non-protein thiol content in maize (zea mays 1.) crops. J. Agro-Environ. Sci. 2020, 39, $964-972$.

77. Zeng, X.-W.; Ma, L.Q.; Qiu, R.-L.; Tang, Y.-T. Effects of zn on plant tolerance and non-protein thiol accumulation in zn hyperaccumulator arabis paniculata franch. Environ. Exp. Bot. 2011, 70, 227-232. [CrossRef]

78. Pal, R.; Kaur, R.; Rajwar, D.; Narayan Rai, J.P. Induction of non-protein thiols and phytochelatins by cadmium in eichhornia crassipes. Int. J. Phytoremed. 2019, 21, 790-798. [CrossRef] [PubMed]

79. Yuan, H.; Huang, G.; Tong, H.; Huang, S. The change of non-protein thiol content in roots and leaves of irislactea var. Chinensis under cd stress. Ecol. Environ. Sci. 2013, 22, 1214-1219.

80. Nishikawa, K.; Onodera, A.; Tominaga, N. Phytochelatins do not correlate with the level of cd accumulation in chlamydomonas spp. Chemosphere 2006, 63, 1553-1559. [CrossRef] [PubMed]

81. Gullner, G.; Uotila, M.; Kmives, T. Responses of glutathione and glutathione s-transferase to cadmium and mercury exposure in pedunculate oak (quercus robur) leaf discs. Bot. Acta 1998, 111, 62-65. [CrossRef]

82. Wang, S.; Chen, Y.; Wang, S.; Lei, J.; Cai, S. Analysis of effects and enrichment of cd stress on thiol peptide protein content of 15 wild vegetables. Southeast Hortic. 2016, 3, 1-7.

83. Wei, Z.G.; Wong, J.W.C.; Zhao, H.Y.; Zhang, H.J.; Li, H.X.; Hu, F. Separation and determination of heavy metals associated with low molecular weight chelators in xylem saps of indian mustard (brassica juncea) by size exclusion chromatography and atomic absorption spectrometry. Biol. Trace Elem. Res. 2007, 118, 146-158. [CrossRef]

84. Couselo Bandin, J.L.; Navarro-Aviñó, J.; Ballester, A. Expression of the phytochelatin synthase tapcs1 in transgenic aspen, insight into the problems and qualities in phytoremediation of pb. Int. J. Phytoremed. 2010, 12, 358-370. [CrossRef]

85. Begum, N.; Afzal, S.; Zhao, H.; Lou, L.; Cai, Q. Shoot endophytic plant growth-promoting bacteria reduce cadmium toxicity and enhance switchgrass (panicum virgatum 1.) biomass. Acta Physiol. Plant. 2018, 40, 170. [CrossRef]

86. Lewandowski, I.; Schmidt, U.; Londo, M.; Faaij, A. The economic value of the phytoremediation function-Assessed by the example of cadmium remediation by willow (salix ssp). Agric. Syst. 2006, 89, 68-89. [CrossRef]

87. LaCoste, C.; Robinson, B.; Brooks, R. Uptake of thallium by vegetables: Its significance for human health, phytoremediation, and phytomining. J. Plant Nutr. 2001, 24, 1205-1215. [CrossRef]

88. Mikhailenko, A.V.; Ruban, D.A.; Ermolaev, V.A.; van Loon, A.J. Cadmium pollution in the tourism environment: A literature review. Geosciences 2020, 10, 242. [CrossRef]

89. Nagatada, T. Rural revitalization with sunflowers as amenity crops in a japanese countryside. Geogr. Rev. Jpn. Ser. B 2010, 82, 78-88. [CrossRef]

90. Fernandez, M.A.; Soulages, O.E.; Acebal, S.G.; Rueda, E.H.; Sanchez, R.M.T. Sorption of zn(ii) and cu(ii) by four argentinean soils as affected by ph, oxides, organic matter and clay content. Environ. Earth Sci. 2015, 74, 4201-4214. [CrossRef]

91. Najafi, S.; Jalali, M. Effects of organic acids on cadmium and copper sorption and desorption by two calcareous soils. Environ. Monit. Assess. 2015, 187, 585. [CrossRef] [PubMed]

92. Yao, W.-Q.; Lei, Y.-K.; Yang, P.; Li, Q.-S.; Wang, L.-L.; He, B.-Y.; Xu, Z.-M.; Zhou, C.; Ye, H.-J. Exogenous glycinebetaine promotes soil cadmium uptake by edible amaranth grown during subtropical hot season. Int. J. Environ. Res. Public Health 2018, 15, 1794. [CrossRef] 